\title{
EFICIÊNCIA TÉRMICA DOS ELEMENTOS DE COBERTURA NO MUNICÍPIO DE TEÓFILO OTONI/MG
}

\author{
IARA FERREIRA DE REZENDE COSTA, M.SC. | UFVJM \\ LUCAS PEREIRA BRAGA |UFVJM \\ ALCINO DE OLIVEIRA COSTA NETO, M.SC. |UFVJM
}

A cobertura é um elemento chave no conforto térmico das edificações, elemento que recebe a radiação solar, durante todo o dia, e tem uma significativa importância no desempenho térmico de edificações térreas. A carga térmica recebida pela cobertura pode atingir valores de $72,3 \%$, em detrimento das fachadas e do piso (MASCARÓ e MASCARÓ, 1992).

A partir deste panorama, o presente trabalho avalia as alterações de temperatura em ambientes internos de um protótipo instalado na cidade de Teófilo Otoni/Minas Gerais, simulando uma edificação térrea com três tipos de cobertura: telhas cerâmicas, telhado verde e uma laje maciça de concreto. As medições da temperatura nesse protótipo permite aferir as características térmicas de possíveis edificações no município, a fim de determinar qual cobertura é a mais eficiente para o conforto térmico.

O protótipo foi coberto em partes, com telha cerâmica colonial, cobertura verde extensiva e uma laje de concreto. Todas as coberturas apresentam as mesmas dimensões $(1,00 \times 1,00 \times 0,80 \mathrm{~m})$ e dispostas nas mesmas condições ambientais, conforme a Figura 01.

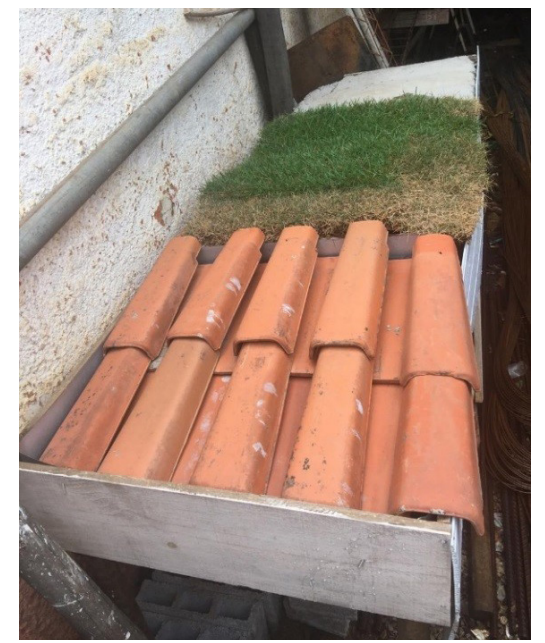

Figura 01 - Vista superior do protótipo Fonte: Autores
Os dados de temperatura foram coletados pelas manhãs, tardes e noites no período de 12 de novembro ao dia 07 de dezembro de 2018, para os três tipos de cobertura e para a temperatura ambiente no mesmo instante. Os horários de coleta foram às $8 \mathrm{~h}, 13 \mathrm{~h}$ e às $18 \mathrm{~h} 30$. $\mathrm{O}$ instrumento de medição utilizado foi o termômetro digital infravermelho com mira laser.

O gráfico da Figura 02 representa os resultados encontrados para a variação das temperaturas médias neste período.

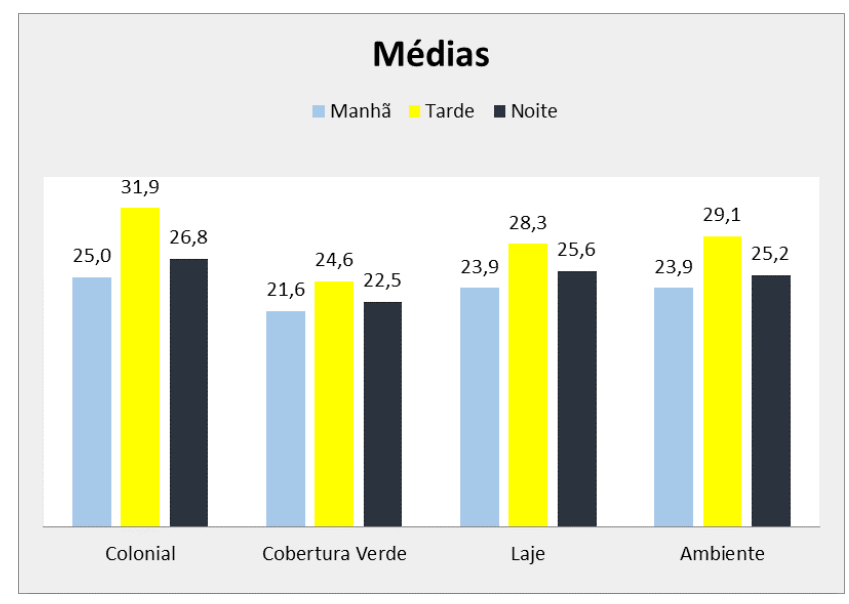

Figura 02 - Temperaturas médias dos ambientes abaixo dos 3 tipos de coberturas Fonte: Autores

Alicerçado no gráfico acima, as coberturas apresentam picos durante o período vespertino, o que já era esperado, uma vez que é durante essa parte do dia que os valores do índice de radiação solar se tornam máximos. Considerando este cenário, a temperatura ambiente obtida foi de $29,1^{\circ} \mathrm{C}$, a temperatura sob uma cobertura coIonial $31,9^{\circ} \mathrm{C}$, na laje maciça, $28,3^{\circ} \mathrm{C}$ e na cobertura verde a média encontrada foi de $24,6{ }^{\circ} \mathrm{C}$. As manhãs apresentam temperaturas menores do que o período da noite, em todas as situações. A justificativa advém pelos valores de índice de radiação solar em detrimento do horário 
estabelecido para a medição (08:00 horas e 18:30 horas, respectivamente), considerando o horário brasileiro de verão no município.

Com referência às medições experimentais, é possível concluir a eficácia do sistema de coberturas verdes, uma vez que este apresentou menores picos de temperatura e as menores oscilações, em comparações com as demais coberturas, considerando as condições climáticas severas do município de Teófilo Otoni. A justificativa para os valores encontrados passa pela caracterização da inércia térmica do substrato, ocorrendo um atraso na transmissão do fluxo de calor proveniente da radiação solar. O protótipo de coberturas foi de grande valia para a obtenção desses dados comparativos.

\section{REFERÊNCIAS}

MASCARO, Juan Luis e MASCARO, Lucia Elvira Raffo. Incidência das variáveis projetivas e de construção no consumo energético dos edifícios: relatório de pesquisa. Porto Alegre; Sagra-DC Luzzatto; 1992. 134 p. 